Marquette University

e-Publications@Marquette

Accounting Faculty Research and Publications

Business Administration, College of

$12-1-2016$

A Case of Fixed Asset Accounting: Initial and
Subsequent Measurement

Jodi L. Gissel

Marquette University, jodi.gissel@marquette.edu

Accepted version. Journal of Accounting Education, Vol. 37 (December 2016): 61-66. DOI. (C) 2016 Elsevier. Used with permission. 


\title{
A Case Of Fixed Asset Accounting: Initial And Subsequent Measurement
}

\author{
Jodi L. Gissel \\ Accounting, Marquette University \\ Milwaukee, WI
}

\begin{abstract}
This instructional case integrates multiple accounting concepts relating to fixed asset acquisition and subsequent measurement. You must apply accounting knowledge, professional judgment, and critical thinking skills to evaluate fixed assets and make recommendations. You must also analyze differences between fixed asset accounting under US generally accepted accounting principles and IFRS. As a student, you generally understand basic application of asset cost computation that simply recognizes the amount of cash paid for acquiring the asset. However, determining asset cost becomes challenging when you encounter more complex situations. You must consider initial measurement issues relating to a land purchase (demolition of existing building and a special assessment expenditure), interest capitalization for a self-constructed building, a nonmonetary asset exchange, and an asset retirement obligation. The case also considers subsequent measurement issues in terms of depreciation (straight-line and accelerated methods), replacement of an asset component, and impairment. The case structure is
\end{abstract}


NOT THE PUBLISHED VERSION; this is the author's final, peer-reviewed manuscript. The published version may be accessed by following the link in the citation at the bottom of the page.

flexible and the teaching notes include alternatives for using scaled-down versions.

Keywords: Fixed asset acquisition; Depreciation; Interest capitalization; Nonmonetary exchange; Impairment; IFRS

\section{Case}

\subsection{Introduction}

Playful Pals, Inc. (PPI) manufactures children toys. The company began operations on J anuary 1, 2015 and has a December 31 yearend. PPI is compiling data about fixed assets for its financial statements prepared under US generally accepted accounting principles (US GAAP). You are to prepare a report addressing issues relating to accounting for PPI's fixed assets. Part 1 considers initial measurement of asset costs and depreciation for the company's first year of operations. Part 2 analyzes events in a subsequent year of operations. Part 3 evaluates how application of International Financial Reporting Standards (IFRS) would impact accounting for PPI's fixed assets. You must research and reference relevant sources throughout your report, as appropriate, to support your conclusions and recommendations. Relevant sources include US GAAP, IFRS, accounting standard setters' conceptual frameworks, and tax regulations.

\subsection{Part 1: initial year of operations}

In 2015, PPI purchased land on January 1 for $\$ 100,000$. When the company purchased the land, there was an existing building on the property. On February 3, PPI paid $\$ 20,000$ in demolition costs to remove this old building. On March 3, PPI paid a \$5000 special assessment to the local municipality for sidewalks on the property. The company also paid $\$ 6500$ on March 3 to install fencing around the property's perimeter. PPI constructed a new building on the property to house its operations. Construction began March 3 and ended June 30. PPI moved into the new building and began using it for operations on July 1 . The company made the following expenditures for construction of the new building: $\$ 125,000$ (March 3); $\$ 100,000$ (April 1); $\$ 75,000$ (May 1); $\$ 100,000$ (J une 2); and $\$ 50,000$ (July 1 ). 
During the construction period, PPI used a portion of the land as a general parking area for other local businesses and area visitors and collected parking fees. PPI collected a total of $\$ 30,000$ in parking fees during the construction period. PPI also purchased the following in 2015: production machinery on January 1 for $\$ 80,000$; office equipment on May 1 for $\$ 7500$; and office furniture on July 1 for $\$ 7000$.

The company also provides the following information regarding its debt. On January 1, 2015, PPI signed a \$300,000 2-year note to finance general operations. Under the note's terms, PPI will make a 10 percent annual interest payment on January 1, 2016. Note principal plus additional 10 percent annual interest is due on January 2, 2017. On March 3, PPI signed a $\$ 400,000$ 4-year note to finance construction of the building. Under this note's terms, PPI will make 8 percent annual interest payments on March 3, 2016, 2017, and 2018. Note principal plus additional 8 percent annual interest is due on March 3, 2019.

All of the above amounts are pre-tax figures. Annual 2015 pretax income before accounting for any of the above items is $\$ 50,000$. PPI 's effective tax rate is 40 percent. Events and circumstances do not suggest impairment of any fixed assets as of December 31, 2015. PPI estimates the new building's salvage value is $\$ 20,000$. PPI does not estimate salvage values for any other fixed assets. Based on manufacturers' specifications and industry reviews for the production machinery, PPI anticipates the machinery will be most productive earlier in its life and that maintenance costs directly correlate with the age of the machinery. However, PPI intends to retain the machinery and use it for as long as possible. In your report, address the following:

- Identify PPI's depreciable fixed assets as of December 31, 2015. For each depreciable asset, make a professional judgment to determine an appropriate useful life. Present a listing of PPI's depreciable fixed assets with the following data: asset item, date placed in service, cost, salvage value, and useful life. Explain your process for determining the appropriate useful lives, citing relevant sources to support your determinations.

- Compute and present annual depreciation expense for December 31, 2015 through December 31, 2019 (five years) for each 
depreciable fixed asset using each of the following methods: straight-line, 150 percent declining-balance, and sum-of-the-years' digits. Discuss the implications of each method of computing depreciation for PPI's results in 2015, citing relevant sources to support as appropriate.

- Recommend a depreciation method for financial statement reporting of each of PPI's depreciable fixed assets, with logical reasoning and justification for your recommendations. (Note: Methods do not have to be the same for all assets.) What is PPI's 2015 net income based on your recommendations?

- Independent of your recommendations, discuss which method you would choose if you are part of PPI 's upper management. Assume you have a cash bonus based on reported net income and intend to stay with the company for three years. Why would you choose this method? Would your choice change if the bonus had an equity component (stock in PPI) and you intend to stay with the company for twenty years versus three years? Why?

\subsection{Part 2: subsequent events in 2019}

PPI implements your recommendations from part 1 (initial year of operations) in 2015 and subsequent years. In 2019, there are four events (detailed below) relating to PPI's fixed assets. Determine how PPI should account for each event. Note that not all of the required situational information may be explicitly present in the given details, requiring your professional judgment and application of critical thinking skills. In your report, provide detailed explanations of your analysis and your judgments at each necessary step to account for the events, with logical reasoning and justification to support your conclusions, citing relevant sources as necessary. Include any required journal entries to illustrate the proper accounting for each event.

Event 1: On April 1, PPI exchanges a computer for a newer one from ExecCorp. The old computer cost PPI $\$ 1500$ as part of the office equipment purchased on May 1, 2015. PPI could have sold the old computer for $\$ 1000$, but decides instead to trade it for a newer computer. The computer PPI receives in the exchange was originally purchased by ExecCorp for $\$ 1900$. PPI also pays $\$ 350$ cash to ExecCorp as part of the exchange.

Event 2: On September 2, PPI installs a replacement roof on the building. The old roof (that originally cost $\$ 60,000$ as part of the

Journal of Accounting Education, Vol 37 (December 2016): pg. 61-66. DOI. This article is @ Elsevier and permission has been granted for this version to appear in e-Publications@Marquette. Elsevier does not grant permission for this article to be further copied/distributed or hosted elsewhere without the express permission from Elsevier. 
building construction in 2015) was in need of significant repairs estimated to cost $\$ 40,000$. PPI chose to instead replace the entire roof at a cost of $\$ 50,000$ cash. (Note: Also discuss if and how this affects accounting for the building in future years.)

Event 3: PPI is in a heavily-wooded area and regularly experiences challenges with cellular communications due to low reception. On October 4, PPI constructs a cellular communications tower on its land at a cost of $\$ 200,000$ cash. PPI obtained permission from the local municipality, but is legally bound to dismantle and remove the tower once it is no longer in use (whenever that is, in the future). The company has several estimates from experienced vendors that indicate the cost of removing the tower in the future will be roughly $\$ 50,000$. PPI also has a legal obligation to perform significant maintenance work and replacement of major components on the cellular communications tower in 2024 . The company has estimates from experienced vendors that suggest the cost of this maintenance work will be roughly $\$ 100,000$.

Event 4: On December 30, PPI evaluates its production machinery. Due to changes in product specifications, one machine (originally purchased for $\$ 45,000$ on January 1,2015 ) is not going to be used in current production, effective January 1,2020 . The machine's market value was $\$ 25,000$ on December 31,2018 . PPI could sell the machine for $\$ 10,000$ on December 30, 2019. However, PPI does not plan to sell or otherwise dispose of the machine. Rather, the company intends to retain the machine in case it has a purpose in the future, even though PPI anticipates the machine will be indefinitely idle. (Note: Also discuss how PPI should account for this machine in future years.)

\subsection{Part 3: implications of applying IFRS}

As noted in the Introduction, PPI prepares financial statements under US GAAP; however, there are some differences when accounting for fixed assets under IFRS. In your report, provide a detailed discussion of how PPI's accounting would differ under IFRS, citing relevant sources. Use PPI's fixed assets in part 1 (initial year of operations) and the events in part 2 (subsequent events in 2019) to

Journal of Accounting Education, Vol 37 (December 2016): pg. 61-66. DOI. This article is @ Elsevier and permission has been granted for this version to appear in e-Publications@Marquette. Elsevier does not grant permission for this article to be further copied/distributed or hosted elsewhere without the express permission from Elsevier. 
make specific illustrations, considering all aspects of accounting for the assets and events.

\section{Teaching notes}

\subsection{Educational objectives}

The case integrates multiple accounting concepts over the fixed asset life cycle. Students must apply accounting knowledge and demonstrate professional judgment and critical thinking skills. The following two subsections detail how the case meets these educational objectives.

\subsubsection{Apply accounting knowledge}

Students consider both US generally accepted accounting principles (US GAAP) and International Financial Reporting Standards (IFRS) applicable to fixed assets. In parts 1 and 2, students apply US GAAP; in part 3, students evaluate how accounting for fixed assets differs under IFRS for the company. At acquisition, basic cost computations for initial measurement simply recognize cash paid to acquire assets. However, determining cost becomes challenging with more complex situations such as purchases of land with special assessments or existing buildings that are then demolished, capitalization of interest costs, nonmonetary exchanges, and assets with future legal obligations. Each of these situations requires a deeper understanding of and ability to apply relevant standards. In the case, students consider each of these initial measurement issues and determine the appropriate capitalized asset costs.

Subsequent measurement requires allocation of asset costs over multiple periods through depreciation. Students assess three depreciation methods (straight-line, 150 percent declining-balance, and sum-of-the-years' digits). Subsequent measurement also requires evaluation of possible impairment, where events or circumstances indicate the company may not recover an asset's remaining book value under the current depreciation schedule. Students evaluate impairment of a machine the company no longer plans to use in current production. The case further incorporates subsequent 
expenditures through building repairs, for which students must determine appropriate treatment (capitalization or immediate expensing). The case also addresses asset disposition through a nonmonetary exchange, incorporating both initial measurement (for the asset received) and disposition (for the asset given up).

\subsubsection{Demonstrate professional judgment and critical thinking skills}

Students demonstrate professional judgment and critical thinking skills, as well as justify their conclusions. Students determine appropriate useful lives for assets and provide support for their decisions. Students also evaluate implications of the depreciation methods and state their recommendations, with logical reasoning and justification. In addition, students consider the choice of depreciation methods, as well as short-term versus long-term implications, from a manager's perspective assuming there is a performance-based bonus. Analysis of the events in the subsequent year of operations also offers opportunities for professional judgment and application of critical thinking skills. For example, with the nonmonetary exchange of the computer, students must recognize the need to compute the fair value of the new computer using the fair value of the old computer plus cash paid in the exchange. Also, students must recognize the need to analyze the monetary portion of the exchange, as this triggers a change in the accounting treatment of the exchange. Students must further apply professional judgment to determine whether the nonmonetary exchange has commercial substance, to evaluate whether the subsequent building expenditure should be capitalized or expensed, to identify an appropriate discount rate and number of periods for the asset retirement obligation, and to assess whether events and circumstances suggest possible impairment of the machine that will no longer be used in production.

\subsection{Implementation guidance}

\subsubsection{Intended audience}

Case material is appropriate for an upper-level undergraduate course or master-level foundations course covering fixed asset

Journal of Accounting Education, Vol 37 (December 2016): pg. 61-66. DOI. This article is @ Elsevier and permission has been granted for this version to appear in e-Publications@Marquette. Elsevier does not grant permission for this article to be further copied/distributed or hosted elsewhere without the express permission from Elsevier. 
accounting (acquisition, subsequent measurement, and disposition). Students should have knowledge of resources available for US GAAP per the Financial Accounting Standards Board (FASB) Accounting Standards Codification (ASC), IFRS, the FASB and International Accounting Standards Board (IASB) Conceptual Frameworks, and tax regulations. Alternatively, instructors may provide a list of recommended sources with the case requirements (see Section 2.3.5).

\subsection{Evidence regarding case efficacy}

\subsubsection{Author's case implementation}

Section 2.3 describes case efficacy based on the author's implementation of a scaled-down version of the case requiring students to complete part 1 of the case (initial year of operations, with a comparison of depreciation alternatives and recommendation for PPI ). The author provided students with asset useful lives and required depreciation computations for 2015 only. The author implemented the case in an undergraduate Intermediate Accounting course. Students completed the case in groups of two or three near the end of the course and had approximately two weeks to complete the case.

\subsubsection{Student case performance}

Twenty-six groups ( 76 students) completed the case. Mean (median) score was 87 (88) percent, ranging from 77 to 94 percent. While overall scores were reasonable, groups struggled with various aspects of the case. Common errors related to land and related expenditures (e.g., depreciated land or misclassified sidewalks and fencing) and appropriate inclusion of building expenditures and capitalized interest as part of asset cost. Many groups also struggled with interest capitalization in terms of properly computing weightedaverage accumulated expenditures, avoidable interest, and actual interest. Other common errors were ignoring partial periods and using the wrong depreciable base for the declining-balance method and using the incorrect denominator for the sum-of-the-years' digits method.

\subsubsection{Student survey feedback}

Journal of Accounting Education, Vol 37 (December 2016): pg. 61-66. DOI. This article is (C Elsevier and permission has been granted for this version to appear in e-Publications@Marquette. Elsevier does not grant permission for this article to be further copied/distributed or hosted elsewhere without the express permission from Elsevier. 
Three days after the case submission deadline, students were emailed a request to complete a brief electronic, anonymous survey. Students were explicitly told responses would not impact grades (responses are anonymous and cannot be tied to identities). Thirtyfour of 76 students completed the survey (44.7 percent response rate). All responses were received within three days of the request, prior to students receiving case grade reports. The survey includes five Likert scale items, with students indicating level of agreement with each statement on a scale of 1 (strongly disagree) to 7 (strongly agree). Table 1 summarizes items with corresponding means, standard deviations (SD), medians, and significance of one-sample Wilcoxon Signed Rank Tests comparing medians to the neutral value of 4 .

Table 1. Student survey responses to Likert scale items.

\begin{tabular}{llll}
\multicolumn{1}{c}{ Item } & N Mean SD Median & $\begin{array}{c}\text { Wilcoxon Signed } \\
\text { Rank Test sig. }\end{array}$ \\
$\begin{array}{l}\text { I found the case engaging and } \\
\text { interesting }\end{array}$ & 345.32 & 1.346 .00 & 0.000 \\
$\begin{array}{l}\text { I found the case challenging for me } \\
\text { individually }\end{array}$ & 345.47 & 1.486 .00 & 0.000 \\
$\begin{array}{l}\text { I found the case to be a good learning } \\
\text { experience }\end{array}$ & 345.71 & 1.516 .00 & 0.000 \\
$\begin{array}{l}\text { After completing the case, I have a } \\
\text { better understanding of: }\end{array}$ & & & \\
$\begin{array}{l}\text { Accounting for fixed assets } \\
\text { Applying depreciation methods }\end{array}$ & 345.71 & 1.406 .00 & 0.000 \\
\hline
\end{tabular}

For all items, median responses are significantly greater than the neutral value $(p=0.000)$. Responses suggest students find the case engaging and interesting, challenging, and a good learning experience. Students also claim a better understanding of accounting for fixed assets and applying depreciation methods after completing the case.

The survey also includes two open-ended questions asking students to identify what they like most and least about the case. The most frequent comments about aspects of the case students like refer to applying knowledge gained in the classroom to a realistic situation and applying multiple depreciation methods. Students' dislikes of the case tend to focus on the need to apply critical thinking skills (e.g., not a clear end-goal; lack of instruction on what to recommend) and the 
timing of the case (near the end of the semester). The comments regarding dislike for the lack of a clear end-goal and lack of instruction on what to recommend are, of course, the point of the exercise to apply critical thinking skills. With regard to concerns for timing of the case, the author recommends implementing the case mid-semester, if the instructor's course plan allows this timing. As is common when requesting feedback, there are aspects of the case some students like, while others do not like the same feature. For example, one student indicates liking the length, while another student mentions this as a dislike; and several students comment on the clarity of case expectations, while others indicate confusion in this regard. Overall, the open-ended feedback is positive regarding the case itself and supports responses to the Likert scale items.

\subsubsection{Recommended solution}

The case solution is available by contacting J odi L. Gissel at jodi.gissel@marquette.edu. A brief summary of items that are located within the solution appears here. The solution presents a sample report based on the author's recommended solution. Student responses vary in areas requiring professional judgment and application of critical thinking skills. However, instructors can use the sample report as a starting point for evaluating students' responses. (Instructors can also refer to the author's grading rubric included in the solution for additional guidance in evaluating students' cases). Students' choices also affect their computations (for example, different useful lives lead to variation in annual depreciation amounts). Therefore, the solution presents details of depreciation computations under the three alternative methods for December 31, 2015 through December 31, 2019 (relating to part 1 of the case) based on the author's recommendations for useful lives and the analysis of subsequent events 1,2 , and 4 under each alternative depreciation method (relating to part 2). An Excel template is available to assist instructors with generating updated computations for different useful lives (including the resulting analysis of the subsequent events in 2019) or different discount rates for subsequent event 3.

\subsubsection{Alternative implementation choices}

Journal of Accounting Education, Vol 37 (December 2016): pg. 61-66. DOI. This article is @ Elsevier and permission has been granted for this version to appear in e-Publications@Marquette. Elsevier does not grant permission for this article to be further copied/distributed or hosted elsewhere without the express permission from Elsevier. 
NOT THE PUBLISHED VERSION; this is the author's final, peer-reviewed manuscript. The published version may be accessed by following the link in the citation at the bottom of the page.

Assign subcomponents of the case: The case structure allows flexibility for instructors who prefer not to assign the entire case (parts 1, 2, and 3). Instructors may assign part 1 (initial year of operations) or part 2 (subsequent events in 2019) of the case individually or assign a two-part case. The solution provides modified case presentations for students for instructors who prefer to use a scaleddown version of the case.

Provide recommended sources: As noted in Section 2.2.1, instructors may choose to provide more guidance to students and, with the case requirements, supply a list of recommended sources within the FASB ASC, IFRS, the FASB and IASB Conceptual Frameworks, and tax regulations. The solution provides both a general list and a detailed list that instructors may use for this purpose.

Follow-up comparison of results in class: The case allows an opportunity to illustrate how flexibility in accounting standards and individual judgments can lead to different results that fall within the confines of accounting standards. For instructors who are able to allow time in class, the author recommends a brief presentation summarizing the students' recommendations. Instructors should highlight the resulting differential impacts on financial statements and facilitate a discussion regarding the comparability of financial statements (referring to the FASB and/or IASB conceptual frameworks) and how management's objectives could conflict with accounting principles. Instructors can further expand this to incorporate differences between financial statements prepared under US GAAP versus IFRS, referring to the sample report in the solution for points to consider.

Group versus individual assignment: The author implemented the case as a group assignment, and received positive feedback regarding this choice. Students enjoyed the ability to brainstorm and consult with group members. However, instructors could easily assign the case to individuals.

\section{Acknowledgements}

Journal of Accounting Education, Vol 37 (December 2016): pg. 61-66. DOI. This article is (C Elsevier and permission has been granted for this version to appear in e-Publications@Marquette. Elsevier does not grant permission for this article to be further copied/distributed or hosted elsewhere without the express permission from Elsevier. 
NOT THE PUBLISHED VERSION; this is the author's final, peer-reviewed manuscript. The published version may be accessed by following the link in the citation at the bottom of the page.

I thank the students who provided comments regarding case participation. I am also grateful for the helpful feedback and suggestions from the editors and two anonymous reviewers.

Journal of Accounting Education, Vol 37 (December 2016): pg. 61-66. DOI. This article is @ Elsevier and permission has been granted for this version to appear in e-Publications@Marquette. Elsevier does not grant permission for this article to be further copied/distributed or hosted elsewhere without the express permission from Elsevier. 